\title{
Research on Informationized Instructional Design in College English
}

\author{
Xiaohui Xu \\ College of General Education, Jinan Engineering Vocational and Technological College \\ Jinan, China
}

\begin{abstract}
Based on the analysis of the guiding significance of educational informatization in college English teaching practice, this paper attempts to construct the basic theory of informationized instructional design and propose the basic principles of college English informationized teaching design. We present the present situation and problems of college English informatization. This study reveals the following findings: (1) exploring effective teaching modes and optimizing the teaching process of informatization; (2) positioning the roles of teachers and students correctly and recognizing the function of informationization; (3) creating effective scenarios to enhance the effect of informationized teaching. In the end, the study discusses the role of teachers in college English informationized teaching.
\end{abstract}

Keywords-Informationized instructional design; College English teaching; Teaching modes

\section{INTRODUCTION}

With the development of intelligent modern information technology which takes multimedia computer and network technology as the core, with the presentation of the research results of advanced cognitive mechanism of human brain science, With the emergence of information-based society based on knowledge economy and the deepening of constructivism theory research, the academic community's understanding of the nature of human learning continues to deepen, and the cultivation of knowledge innovation talents has become an urgent practical need of society [1-2].

The design of informatization instructional teaching is a teaching design based on the background of information age by the means of information technology, through various advanced learning theories, and the core idea of cultivating learners' ability and innovative spirit in the information age.

Information society is a global integration of society and a learning society. It urged our new generation to have an international outlook, a good information literacy, an emphasis on the independence and creativity of the human being as an individual, an appreciation of individuality and the full development of the soul, and an emphasis on cooperation and effective interaction with others as a member of society. The new social demand causes the education from the utilitarian value orientation to pay more attention to the individual own development value orientation. The traditional teaching design is contrary to the educational concept centered on students and their learning process in the information age, and runs counter to the educational value orientation in the information age.
Therefore, the putting forward of the information teaching design is inevitable.

\section{THE GUIDING SIGNIFICANCE OF EDUCATIONAL} INFORMATIZATION IN COLLEGE ENGLISH TEACHING PRACTICE

\section{A. Education informatization makes college English teaching and learning more flexible and diversified}

The wide application of information technology in college English teaching is bound to have a profound impact on the teaching process. New media and technology provide the conditions and basis for enriching teaching methods. Teachers have a wider range of choices and richer creative space in the teaching process.

\section{B. Educational informatization changes traditional college English teaching modes}

The characteristics of the traditional college English teaching mode are mainly classroom teaching, emphasizing students' comprehension, and students' individual work. The teacher is omniscient and the content is archaic and monolithic. This kind of inculcating teaching greatly limits the learner's independent learning and can not adapt to the rapid development of information technology and new educational concepts. The establishment of Internet platform supported by information technology enables every learner to learn in his own way and makes autonomous learning inevitable.

Education informationization constructing a good new relationship between learning and teaching under the impact of information technology, the teacher's duty is no longer simply to focus on knowledge indoctrination, but to develop in the direction of multipolarization, playing a role in knowledge, behavior navigation, emotional communication and so on. Modern teaching information network provides us with rich and colorful teaching information. Teachers should rely on their own experience and macro grasp of English knowledge to change some contents in traditional textbooks according to the needs of the curriculum. Teachers should use modern educational information technology to design and develop teaching resources that meet the needs of the Times, and organize the teaching forms and strategies of college English courses. 


\section{THE PRESENT SITUATION AND PROBLEMS OF COLLEGE ENGLISH TEACHING INFORMATIONIZATION}

\section{A. The oretical research aspects}

In our country the relevant research in this field is seldom involved in the data literature, there is not a sufficient theoretical basis, just for reference to the pedagogy and the individual theory of psychology, for its unique characteristics, development research is not deep enough. The lack of theoretical support has led to the slow and inefficient process of college English information teaching in China, which makes it impossible to provide students with high quality and high efficiency English teaching in the true sense of the word.

\section{B. Supporting facilities in teaching}

In most colleges, the level between the teaching facilities, information technology and English teaching situation is not balanced resulting in daily English teaching teachers can not give full play to the corresponding role of facilities. In the development of facilities and technology, we neglect to use the application scheme corresponding to the informationized teaching of college English, which leads to the low-level application of high-end equipment and high-end technology, which is a waste of resources as well as funds.

\section{The overall level of society}

With the globalization of the world economy and the rapid development of information technology, society has entered the information age, which also means that the transformation of education information has become an inevitable trend. The informationization of college English teaching can not be separated from the social background and support. However, in the current practice of college English information teaching, there exists a phenomenon of lower overall level, which results in a very weak effect on the teaching of English information. The whole society cannot receive the feedback of the effectiveness of the information teaching, which leads to the reduction of the support for the teaching of English information, which worsens the development of college English information teaching.

\section{THE PRINCIPLES OF INFORMATIONIZED TEACHING DESIGN IN COLLEGE ENGLISH}

The design of teaching mode should emphasize the two goals focusing on cultivating students ' creative ability and active thinking operation skill, which should be reflected from student-centered in the course of teaching pattern design. The design of the whole information teaching mode is hierarchical, and the level of learners may be uneven in the middle. According to the actual situation, the teaching schedule and design need to be adjusted to adapt to the teaching mode. We should focus on the creation of an information-based learning environment and the provision of appropriate learning resources.
In the information teaching situation, the design can follow the following principles. Make full use of all kinds of information resources to conduct effective learning, focus on improving the problem analysis and solving ability; To develop learning skills and strategies in related contexts, emphasizing collaborative learning; Attach importance to the cultivation of learners' independent learning ability; Emphasize the evaluation of learning effect in learning process and resource utilization.

According to the above principles and the characteristics of college English discipline, the following three aspects should be paid attention to in the design of English information teaching:

\section{A. Design English situational topics}

We should determine the direction of teaching knowledge framework, progress and theme according to the different characteristics and emphasis of teaching materials and the construction of the distribution of each unit on the basis of the analysis of learning goals.

\section{B. Creat English Learning Scenarios}

When designing teaching links, we should make full use of multimedia information technology resources, which have the advantages of interesting, strong information capacity and audio-visual integration. According to the needs of teaching and learning, we can download resources from the Internet that are conducive to the creation of teaching situations, promote the enthusiasm and initiative of learners, restore the real English language application environment, and optimize the teaching content. This kind of lively and audio-visual combination of teaching information can easily arouse students ' attention and interest, enable students to use the language in the actual situation of communication, strengthen teachers and students, students and students interaction and language communication.

\section{Design of the Autonomous Learning Mode}

According to the different teaching methods we have chosen, we should make different designs on students' autonomous learning styles in the design of English information teaching. In this link, we should give full consideration to the theme of reflecting the development of students as the center, give full play to the initiative and enthusiasm of students in the learning process, and embody the spirit of innovation of students. In different English situations, students can have a variety of opportunities to externalize knowledge into learning outcomes. Students can self-review and test the learning results. 


\section{V.CONCLUSION}

\section{A. Exploring effective teaching modes and optimizing the teaching process of informatization}

It is the core of college English teaching to explore the effective integrated teaching mode of information technology and college English teaching. Because English learning is a complicated cognitive process, students should have enough time and opportunity to think, comprehend and experience in the process of learning. There are many positive methods in traditional teaching, such as asking students to take dictation or notes. Only those parts that cannot be presented by traditional means can be presented by information technology to achieve unexpected teaching effects. Teachers should make a lot of preparation before class, select the learning materials according to the teaching content. The teacher demonstrates in class according to the student's level, but must solve the problem of the amount and degree of the use of information technology, otherwise half the effort.

\section{B. Positioning the Roles of Teachers and Students Correctly and Recognizing the Function of Informationization}

English is a very practical subject. Students' ability to use language can be cultivated only through a great deal of communication between teachers and students. Therefore, students' subjective consciousness should be strengthened and students' subjective initiative should be brought into full play in the process of informatization. At the same time, it should be made clear that teachers are helpers, guides and promoters in the teaching process. We should always take students as the center, make use of situations, cooperation, conversation and other ways to give full play to students' subjective initiative, and finally achieve the goal of enabling students to master English. Information technology is only a tool to assist teachers in teaching and can only serve the function of teaching. It can not completely replace the teaching activities of teachers and students in the classroom. Therefore, in the process of informationization we should not only pay attention to the optimization of the technical level, but also highlight the main body and dominant position of students and teachers. The role of teachers and students in the classroom is not and cannot be replaced by computers. In the actual classroom teaching, there are many links that can not be replaced by computers, such as English speech in the first few minutes of class, students dictation exercises and recitation of the text, teachers check the students' grasp of words and so on.

\section{Creating Effective Scenarios to Enhance the Effect of Informationized Teaching}

Multimedia networks have unique advantages in creating English situations and developing students' listening, speaking, reading and writing abilities. It can be used to create real or virtual language environment for students to create immersive language situations, so that students participate more in language practice. First, we can use English movie DVD or network means to show some films about the culture, history, geography, life and work scenes of English-speaking countries, so that students can enjoy the atmosphere of English-speaking countries, understand the differences between different countries in social culture, customs, habits, communication and other aspects, feel the way of thinking of Englishspeaking countries, familiar with their phrasing and phrasing habits, so as to avoid the occurrence of Chinese-style English. Second, reasonable use of some voice listening and speaking equipment in English classroom, so that students feel and memorize authentic English vocabulary and grammar, while training their oral and listening. In teaching practice, teachers can also use such phonetic equipment to ask students to discuss and write on a special topic, to develop students' oral and written expression ability, improve language sense. College English teaching by means of modern information technology can not only stimulate students' senses such as eyes, ears, hands and brains at the same time, but also enable students to actively participate in the learning process all the time, effectively arouse students' interest in learning, fully arouse the initiative and enthusiasm of students' cognitive subject, give full play to the advantages of man-machine communication, promote the fast pace, large capacity and high efficiency of classroom teaching, and improve the quality of English teaching.

With the rapid development of information technology, the trend of social development and the needs of the modern talent market are prompting the reform of teaching, the aspects and levels of reform become more detailed and in-depth, we will also increase the use of information technology more and more widely. Informatization education is now in a developing stage, and information technology, as a new impetus based on digitalization, lays a blueprint for the development of the quality of English teaching.

In the era of rapid development of the Internet, the integration of information technology and English curriculum has become an inevitable trend. Teachers should fully understand and comprehend the connotation of information teaching design, take the initiative to use advanced information technology, optimize teaching mode, Integrate teaching resources, innovate teaching methods and means, strengthen learning behavior and effect, adjust the relationship between teachers and students, improve the overall level of college English teaching.

\section{REFERENCES}

[1] Gaoda He ,Zhiying Zhong, A Study on the Adaptability of College English Teaching and Learning under the Multimedia Technology Environment [J], Foreign Language2007(2).pp 65-67.

[2] Wenyang Liu , On the Application of Chinese Culture in the Teaching of "Chinese English"[J]. Crazy English (Teacher edition), 2015 (1).pp5254.

[3] Shuanghua Jiang, Classroom Design of English Teaching in Higher Vocational Education from the Perspective of Information Teaching, Research on curriculum Education2017(09) pp73-74.

[4] Qian Wang, Research on the Information Teaching Ability of English Teachers in Higher Vocational Colleges Based on the Information Environment, Knowledge Base 2018(4)pp 35-37.

[5] Liang Zhu, On the Classroom Design of English Information Teaching in Higher Vocational Colleges in the Age of "Internet +" Modern vocational education,2017(27).

[6] Bardovi-Harlig K Bastos M-T. Proficiency,Length of stay, and interaction and the acquisition of conventional expressions in L2 pragmatics [J]. Intercultural Pragmatics,2011,(8):pp 347-384. 